\title{
The Geodynamic Evolution of the Indian Subcontinent- An Introduction
}

\author{
1* Corresponding author. Geological Survey of India (Rtd.), 1532, 14th Main, K.A. Layout, Bangalore-560078. \\ Email: fareedromani@gmail.com \\ 2 Department of Geology, University of Delhi, Delhi-11007 \\ 3 Department of Geology and Geophysics, Indian Institute of Technology, Kharagpur, India \\ 4 Department of Geology, University of Lucknow, Lucknow, India \\ 5 CSIR-Central Building Research Institute, Roorkee-247667, India \\ 6 Wadia Institute of Himalayan Geology, 33 GMS Road, Dehradun 248 001, Uttarakhand, India \\ 7 National Centre for Polar and Ocean Research, Goa 403804, India \\ 8 CSIR-National Geophysical Research Institute, Uppal Road, Hyderabad, INDIA
}

https://doi.org/10.18814/epiiugs/2020/020001

\section{Introduction}

Geology of the Indian subcontinent is not only diverse and interesting but also has been studied for a long period. Reflection of a rich geoscientific heritage may be illustrated by a couple of lesser known early or first "discoveries/descriptions" from the Indian subcontinent. Heinrich (1966) in his book "The Geology of Carbonatites" mentions that the first description of carbonatite was provided from India by Bose (1884) as quoted below (italics and bold for emphasis);

"Actually the first published description of a carbonatite predates Hogbom (1895) by about a decade. Bose (1884) found $^{1}$ in the Lower Narbada Valley in west central India masses "of yellowish altered calcareo-siliceous rocks" forming the crest of basalt-covered ridges. He noted (1) that these rocks were more resistant than the basalts to weathering and erosion; (2) that they were not bedded; (3) that they contained no fossils; (4) that they were "fine grained but crystalline"; (6) that they were markedly calcareous with local "nests and patches of a tappean-looking ${ }^{1}$ substance" the igneous origin of which is manifest under microscope ( $p$ 54); (6) that the outcrop distribution was linear and straight, and (7) that locally associated was "highly altered and intensely hardened slates and siliceous rocks" ( $p$ 59). He concluded (P. 60) that "there can be very little doubt that ..... the rocks under notice have been severed and forced up from the infra-trappean beds by intrusive rocks. They have been most effectually baked, being rendered quite crystalline ....... and portions of them would appear to have been converted into a trappean substance".

1 either xenoliths of basalt or aggregates of silicate species.

Similarly, one of the earliest observation of seismology and movement associated with recent seismic events is reflected in the following description by La Touche (1919).

"The existence of a number of forest trees, submerged to a depth of some 20 feet below mean sea level, but in many cases still retaining their upright position and with their root attached to the soil in which they grew, were brought to light during the excavation of the Prince's Dock in the eastern side of Bombay Island about the year 1878. Observations made at the time by Mr. G. E. Ormiston, Resident Engineer, Bombay Port Trust, were communicated by Government to the Records, of the Geological Survey of India (XIV, pt. 4, p. 302) accompanied by a note by Mr. W T Blanford, pointing out that the discovery furnishes evidence of a depression of the land surface in the immediate neighbourhood of ground which appears to have been recently elevated since it has been shown by Dr. Buist (Transactions, Bombay Geographical Society, VX, p. 179) that a raised beach, composed of shelly gravel partly consolidated into a 'littoral concrete' is found at many places on the western side of the island, extending to a height of 12 feet above high water mark.

Further details of the occurrence supplied by Mr. Ormiston, were published in a subsequent issue of the Records (vol. XIV, pt 4, p. 320) with notes by Mr. H B Medlicott, in which it is stated that samples from the trees insitu have been identified by Mr. J. Sykes Gamble, Conservator of Forests (Bengal) as that of Khair ( Acacia catechu), a well known Indian Forest tree inhabiting the drier parts of the Indian Peninsula, both inland and in the neighborhood of the coast, but not known to occur below the level reached by the tides. Two of the samples were also recognised as teak; but these were from fallen logs, which had apparently been drifted to the position in which they were found. The total number of trees uncovered within an area of 30 acres was 382, of which 223 were erect stumps. One of the fallen logs 
measured 16 feet in length with a girth of 36 inches; but stumps reaching 4 feet 6inches in girth were also met with'.

P-219. 'We have of course no means of knowing whether

the final phase of the movement in Bombay harbor was accompanied or not by seismic disturbances; but the abrupt manner in which the deposition of blue clay appears to have come to an end, and to have been followed by a sudden influx of the sea, seems to lie in favour of such a supposition'.

Taking into account the diversity of geology, both in terms of the spread of geological time i.e. Hadean to Recent, as well as that of the material and structures i.e. vast variety of rocks and minerals and stable cratons to the youngest and active mountain chain of the planet earth, it presented a difficult challenge to create a legacy publication which captures review and status of representative multifaceted geoscientific data. Using a survey from eminent geoscientists and considering the practical issues, a total of forty two titles were agreed upon by the Legacy Committee of the 36 IGC. These papers constitute the present special issue of Episodes. Ten section editors made very special efforts to make it possible to complete the process from invitation to peer reviews to revision/s within a time of 18 months. Timely completion would not have been possible without their yeomen's efforts.

In the following paragraphs, a brief introduction of the Indian sub continent is followed by introductions of each paper by respective section editors.

\section{The Indian Sub-continent}

The Indian Sub-continent is a mosaic of Archean cratons, Proterozoic mobile belts, intracratonic sediment dominated Proterozoic basins and post-Cambrian cover sequences (Fig.1). The major Archean cratons are Dharwar in the south, Bastar and Singhbhum in the east, Bundelkhand in the center and Aravalli in the northwestern parts. These cratonic regions have developed peripheral strips of intensely deformed and metamorphosed supracrustal rocks referred to as mobile belts. The prominent mobile belts of the subcontinent are Southern Granulite belt fringing Dharwar Craton, Eastern Ghat Mobile Belt bordering Dharwar, Singhbhum and Bastar cratons and Aravalli-Delhi mobile belt stitched with Aravalli Craton. Besides these, there is an inter-cratonic Satpura mobile belt/Central Indian Tectonic Zone partially sandwiched between SinghbhumBastar and Bundelkhand cratons. The Himalayan Orogenic belt bounding the Indian subcontinent towards north is largely a Tertiary orogen developed over a Precambrian basement. The intracontinental Proterozoic sedimentary basins, referred in earlier literature as 'Purana Basins' represents thick accumulation of up to $10,000 \mathrm{~m}$ of flat-lying virtually unmetamorphosed rock strata. These are widespread in northwestern, north-central, east-central and southern parts of India. Prominent among these are Marwar, Vindhyan, Chhattisgarh, Cuddapah, Bhima and Kaladgi basins. The major post-Cambrian geological units in the sub-continent include (i) vast flood basalt province at the Cretaceous-Tertiary boundary, known as Deccan Volcanic Province in western and central India (ii) Rajmahal and Sylhet Traps in eastern India, (iii) Coal-bearing Gondwana successions in Damodar, Satpura, Mahanadi and Godavari rifts in eastern and central India (iv) Cretaceous marine sediments in Narmada Valley, Tiruchirapalli (Cauvery Delta) and in Meghalaya respectively in westcentral, southern and northeastern parts of India, (v) Coastal Tertiary and Quaternary sediments (vi) Holocene (Recent) sediments along major river valleys; Tertiary and Quaternary sediments at the foothills of Himalaya and in Indo-Gangetic and Brahmaputra plains (including the Bengal and Indus fans), (vii) a vast expanse of desert region towards northwestern parts of India and (viii) a linear array of recently erupting volcanic centers that are being continuously accreting material from a full-fledged modern accretionary convergent margins in Andaman Sea. Distribution of diverse rock units in space and time, undoubtedly, is the hall mark of the Indian subcontinent. In this special issue vivid details of the most of aforementioned tectonic domains are presented in order to chronicle the geotectonic developments throughout the geologic past.

\section{Hadean to Archean records from India- insight into early crustal processes}

Indian terrain is fortunate in having several large Archean cratonic nuclei which can provide information not only on the evolution of the early earth but also contain clues to the evolution of the atmosphere. The Hadean eon, representing 4567-4030 Ma period, however, has very little representation in these studies and it will be pertinent to make a mention of this period. Formation of earth's core and differentiation of upper and lower mantle is generally considered to have taken place quite early (within 30Ma) of earth's formation (Kleine et al. 2002; Boyet and Carlson, 2006). In the absence of any preserved terrestrial material of very early earth, many of these inferences have been drawn from short lived isotopes. Extraction of melt from mantle is indicated by isotope based data such as Sm-Nd model ages (Moorbath et al. 1997) but these could be affected by later reworking such as metamorphism. Singularly the most important material to study the Hadean eon (as well as that of the Archaen eon) has been detrital zircon. There have been several approaches to interpret the Hadean eon. Retrieval of Hadean ages, of course, forms the primary step and techniques involved in this have evolved steadily. The major technological advancement has been development of insitu measurements such as Laser-Ablation inductively coupled spectrometry (LA-ICPMS) (Harrison et al. 2005; Kemp et al. 2010), secondary ion mass spectrometry (SIMS) (Valley 2003) as well as atom probe tomography (Valley et al. 2014).

Other chemical parameters such as Lu-Hf isotopes in zircon have been used to interpret a reworked source in zircons recovered from orthogneisses (Iijuka et al. 2009). Out of the known reports of $>4.0$ Ga zircons including those from Canada (Acasta Gneiss; Iizuka et al. 2013), Greenland (Itsaq Gneiss; Mojzis and Harrison, 2003), North China Craton (Cui et al. 2013) and Tibet (DuO et al. 2006) the earliest reports from the Yilgarn Craton in Australia (e.g. Froude et al., 1983; Compston and Pidgeon, 1986) from a 3.0 Ga metasedimentary unit have received maximum attention (e.g. Whitehouse et al. 2017 GR). Along with these, experimental calibration such as $\delta \mathrm{O}^{18}$ measurement for application such as redox state of melt or nature of magma from which zircons crystallized (e.g. Harrison et al. 2008; Trail et al. 2013) or calibration of $\mathrm{Ti}$ in zircon as a thermometer (Watson and Harrison 2005) also provided a window of the material and processes operative during Hadean eon.

Hadean ages from zircons have been reported sparsely from the Indian sub continent. These include Hadean (Upadhayay et al. 2014, Chaudury et al. 2017, 2018, Chaudhury and Mazumder, 2019, Miller et al. 2018 and 2019) and Eoarchaen (Sreenivas et al. 2019) detrital 


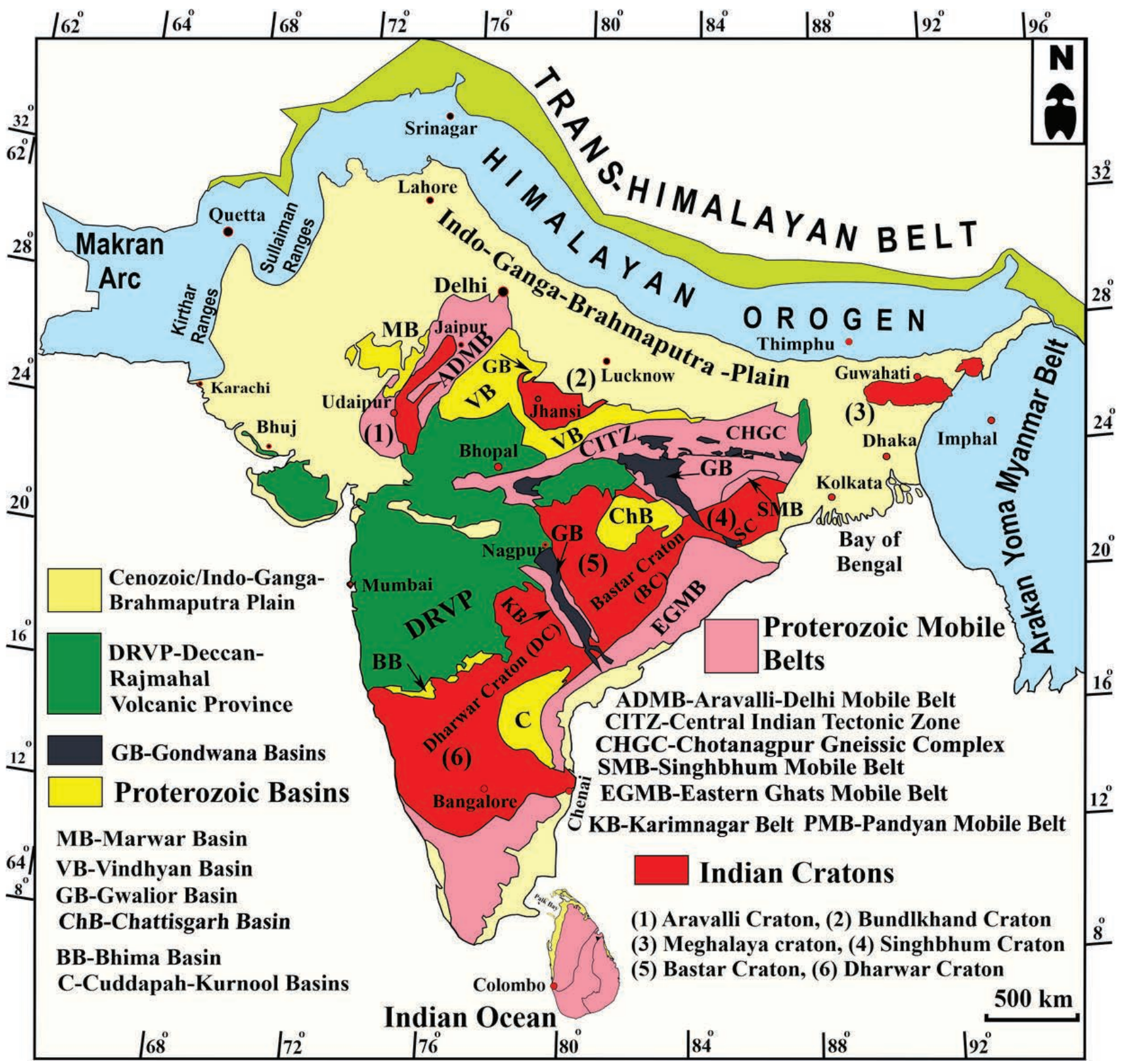

Figure 1. Geology and tectonics of the Indian Sub-continent, showing its main characters (compiled by AK J from various published sources).

zircons reports from Singhbhum craton wherein the coupled isotopic data has been used extensively to comment upon the nature of mantle reservoir during the early earth crustal accretion processes. Using Zircon U-Pb in conjunction with Lu-Hf data, Santosh et al. (2016) inferred vestiges of Neohadean continental crust in the Coorg block towards south western Dharwar craton.

With greater emphasis on Paleoarchean and younger events, the three papers in this section not only review the status of knowledge on the Dharwar, the Singhbhum and the Bundelkhand cratons but also provide a critical analysis of the multiple theories of their evolution.

Bhaskar Rao et al. provide a review of Paleo- to Neoarchean crustal evolution of the Dharwar craton and examine it in context of craton specific evolution of plate tectonic processes in their article on the Dharwar Craton. They utilize and combine geological data with the geophysical and the geochronological data to interpret a billion year geological history from 3.5 to $2.5 \mathrm{Ga}$. Preservation of middle to deep crust and operation of vertical tectonics in the early part of this period followed by convergent plate tectonics during Neoarchaen is described.

Jayant Pati in his review article entitled "Evolution of Bundelkhand Craton" focuses not only on the Paleoarchean magmatism but also compiles evidence for Archean subduction and metamorphism but also on its linkages with the silico-thermal fluid activity and plumelinked magmatism. The highlight of the craton is the report of highpressure metamorphic assemblage indicating an Archean subduction- 
like setting, rarely preserved in such cratons. Similarities with other Indian Archean cratons has been used to suggest linkages to the Ur supercontinent assembly.

Mukhopadhyay and Matin in their exhaustive review of the Singhbhum craton describe pulses of discrete granite magmatism as the craton building process and infer that this began during Hadean time and continued through Eoarchean. Isotopic data has been used to infer the nature of reservoir of these magmas as well as the evolution of the source. Plume-driven and subduction-driven mechanism of crust formation have been critically evaluated and the supracrustal Older Metamorphic Group (OMG) is inferred to have formed in suprasubduction setting. These authors also refer to the Hadean period in this craton.

The three reviews not only provide a succinct summary of the early crustal evolution but also bring out points of comparison as well as gaps in knowledge.

\section{Proterozoic Mobile Belts}

Archaean cratons within a Precambrian shield are separated by mobile belts - segments of the crust that are intensely deformed and have undergone metamorphism at a grade higher than that experienced by the adjoining exposed levels of the craton. The parallels with modern plate tectonic scenarios are striking, as new continents are constructed by collision of continental fragments following consumption of intervening oceans. It is tempting to presume that Precambrian mobile belts represent ancient collision zones, but the challenge to such a hypothesis lies in proving the existence of ancient oceans between the cratons, evidence for which is understandably ambiguous. The Indian shield is no exception to this structure, and a number of cratons constitute the bulk of peninsular India. As elsewhere, these cratons, or cratonic fragments, are separated by mobile belts that are more intensely deformed, metamorphosed and younger in age than the bounding cratons. Documentation of these mobile belts involves characterization of their internal anatomy with respect to their lithological set-up, structure and the age of the various thermal events, and the nature of their contacts with the craton.

In this section, four key mobile belts that fringe major cratons of the Indian peninsula are documented and updated. Santosh (2020) presents a comprehensive account of the current thinking about the Southern Granulite Terrane (SGT), which defines the southernmost part of the peninsula, south of the Dharwar Craton. It appears that the SGT is itself composed of a mosaic of several crustal blocks ranging in age from Mesoarchaean to Neoproterozoic-Cambrian, contains invaluable information about lower crustal processes and even preserves signatures for the emergence of continental crust above sea-level. Arc magmatism, ultrahigh temperature metamorphism and accreted ophiolite complexes along the margins of many of these blocks suggest involvement of the SGT in several cycles of supercontinent formation. In contrast to the older granulites of the SGT, Dasgupta (2020) reviews the metamorphism of the celebrated granulites of the Eastern Ghats Belt (EGB), that fringe the east coast of the peninsula to the east of the Dharwar and Bastar Cratons. Correlation of the metamorphic conditions and P-T paths with a rapidly expanding geochronological database confirms association of the EGB with the Prydz Bay region of East Antarctica at least till $0.5 \mathrm{Ga}$, and reveals possible signatures of Columbia and Rodinia assembly and break-up within the EGB. Chattopadhyay, Bhowmik and Roy (2020) highlight the long-lived ( 1000 Ma; 2.9-0.9 Ga) tectonothermal history of the Central Indian Tectonic Zone (CITZ), that effected amalgamation of the northern and southern Indian cratonic blocks to form the Greater Indian Landmass (GIL). Compiling the currently available petrological, structural and geochronological data in this area, they argue that the CITZ also preserves substantial evidence for assembly and dispersal of the Columbia and Rodinia supercontinents. Finally, Fareeduddin and Banerjee (2020) describe the Aravalli craton and its mobile belt (the Aravalli-Delhi Mobile Belt, ADMB), that forms the western part of present-day Indian nation. Their compilation confirms that an Eo-Palaeoarchaean protocontinent survived in the Aravalli mountain belts through a series of Palaeoproterozoic to late Mesoproterozoic orogenic events (1.72-1.0 $\mathrm{Ga}$ ). They review the stratigraphic status of the Banded Gneissic Complex, and the Aravalli and Delhi Supergroups, and importantly, suggest that an Eo- to Palaeoarchaean Marwar craton may once have existed to the northwest of the Aravalli craton.

The comprehensive reviews of these four key mobile belts in the Indian Precambrian outline one commonality - the involvement of the mobile belts in thermal events connected to the supercontinents of Columbia and Rodinia. Interestingly, only the SGT and the EGB preserve evidence of a $\sim 0.5$ Ga Pan-African event; this appears to indicate that the CITZ and ADMB were already distant from the frontal orogens that amalgamated Gondwana. The implications for the evolving palaeogeography of the present-day Indian landmass through the Proterozoic are exciting, and define the pathways for research through the next decade.

\section{Proterozoic Cratonic Basins}

Stabilization of cratons with emplacement of granitoids, stitching of Archean cratonic nuclei with polyphase orogenic belts, and opening and closing of intra- and epi-cratonic sedimentary basins on stabilized craton/s register the $\sim 3.0$ billion years Precambrian odyssey of the Indian subcontinent. In this backdrop, role of the Indian cratons in the amalgamation and fragmentation of supercontinents through time is a poorly understood and a highly debated topic. Indeed, recent studies have attributed the origin of several pericratonic sedimentary basins (rift-related or foreland) to dispersal or amalgamation of supercontinents, viz. Columbia, Rodinia and acknowledged the necessity for the study of depositional histories of these basins in order to obtain more clues related to reconstruction of supercontinent architecture. Patranabis-Deb and Saha in their contribution made an attempt to summarize updated information from the Proterozoic basins of India and discussed the data in the backdrop of two Supercontinents viz. Columbia and Rodinia.

Two other topical issues of global interest in Precambrian sedimentology are i) role of microbes in Precambrian clastic sedimentation process and structures induced by microbial mats, and ii) Oxygenation of Precambrian atmosphere and hydrosphere. Indian cratonic basins are treasure house of Microbial mat Induced Sedimentary Structures (MISS). Sarkar et al. have nicely summarized the microbial features from these basins and discussed role of microbes behind framing of these structures. Acknowledging nonexhaustiveness of data, Chakraborty et al attempted summarization of signatures from paleosol, iron formation rocks, carbonates, phosphorites and argillites related to oxygenation history of atmosphere and hydrosphere. Analyzing sulfur isotope (sulfide and sulfate) and redox-element (Mo, Cr etc.) data obtained from Indian 
cratonic basins these workers concluded that the deep ocean was anoxic, in general, and at times euxinic trough major part of Proterozoic time.

\section{Proterozoic Magmatic Events}

Proterozoic magmatic events represent a time span equaling nearly half of the 4.4 Ga Earth's history (2.5-0.54 Ga). Also, we are celebrating 50 years of the Wilson Cycle concept (1969), which eventually led to conceiving modern plate processes (see Wilson et al., 2019 for details), considered in action surely since Proterozoic.

Understanding the Proterozoic magmatic events is critical to the origin and evolution of thicker crust and oxygenated atmosphere. Although the 'subduction' model largely explain the origins of granitegreenstone belts and granitoid batholiths, important questions remain. For instance, episodic continental crustal growth recorded at or about 2.7, 1.9 and $1.2 \mathrm{Ga}$, crust with higher $\mathrm{Ni}$ and $\mathrm{Cr}$, low preservation of Ca-boninites, complementary trace elements for continental and oceanic crust by depletion of the primitive mantle area are explained with direct mantle contributions including mantle plumes. Of course, none of the hypotheses is favoured in cases, or different tectonic models may coexist within a single thermal regime.

The Proterozoic magmatic record in India is fragmentary, yet diverse and widely distributed (see Naqvi, 2004). It is not intended to discuss all problems here. Nevertheless, few issues deserve mention. The Paleoproterzoic high Mg basalts (MgO 8-10 wt\%) in unrelated terrains (e.g., Dalma basalt in Singbhum, Mahakoshal basalts, Dongargarh high Mg basalts in central India Shield) show primary Fe-rich character ( $\mathrm{FeO} \geq 10 \mathrm{wt} \%$ vs. $8.07 \mathrm{wt} \% \pm 0.006$ in upper mantle) suggestive of Fe-rich deeper source, including possible lower mantle contribution. Also, whether elevated Si- and mantle incompatible elements in high MgO basalts are attributable to crustal contamination/ crust-mantle melts interactions in a rift setting, or crustal input through subduction, or titanite \pm rutile in source in producing "subductionlike” $\mathrm{Nb}-\mathrm{Ta}$ minimum in spidergrams require critical inquiry. Study of deep supercritical fluid in lower crustal melting, magma mingling/ mixing in open-systems and juvenile input and crustal reworking over $\sim 1$ billion years in granitoid production are getting attention. The origin of ferroan feldspathic rocks (granite/quartz syenites/foid syenites), sometimes with anorthosites is also of interest. Crust-mantle interactions in bimodal LIP, unlike sole mantle- (mafic LIPs: dyke swarm in Dharwar craton) or crust-melting (silicic LIPs: Malani), and supercontinent reconstruction by matching synchronous pieces of LIPs are breaking new grounds. Examining granitoid-rhyolite link, including origin of low- $\delta^{18} \mathrm{O}\left(\delta^{18} \mathrm{O}<5.5\right)$ crust-derived rhyolite (crust: $\delta^{18} \mathrm{O}>7$ ) remains a major area of study.

The primary goal of this section is to help emerge the larger picture of the Proterozoic magmatism in India by bringing together thematic reviews. Four papers related to Proterozoic mafic, silicic, carbonatitealkaline, lamprophyre-kimberlite magmatism are incorporated in the section. In the first paper, Radhakrishna and Vijaya Kumar, using $\mathrm{U}-\mathrm{Pb}$ ages and palaeomagnetic results, has identified at least four discrete Paleoproterzoic mafic magmatic events at 2.36-2.37 Ga, 2.12.2 Ga, 2.1-2.0 Ga 1.99-1.89 Ga and probably other events ( 2.4 Ga, $1.8 \mathrm{Ga})$ in the Indian Shield. These thermal events, manifested as mafic dyke intrusions and/or as traps/intrusive, are related by fractional crystallization of sub-continental lithosphere mantle (SCLM)-derived magmas, with little crustal assimilation, caused by impinging mantle plumes. However, SCLM metasomatism by subduction-related sediments and/or silicate melts is ruled out. Next, combining field, petrography, whole rock elemental and isotopic constraints, and zircon-baddeleyite geochronological data, Santosh Kumar et al reviewed and discussed Proterozoic felsic and mafic magmatism in India (including in the Himalayas) and their implications to crustal evolution through crust-mantle interactions in volcanic/subvolcanic/ plutonic environments in diverse tectonic settings. Meso- to Neoproterozoic magmatism appears mostly occurred in the Bastar and Dharwar cratons, whereas the Aravalli-Delhi orogen hosts a number of Neoproterozoic events. Mafic-felsic magmatism in India seem linked to assembly and break-up of Columbia and Rodinia supercontinents. Chalapathi Rao et al present an overview on lamprophyres- alkaline, calc-alkaline and ultramafic types- and their relations with kimberlites.Theultramafic lamprophyres are confined to rift zones, whereas calc-alkaline lamprophyres are plausibly linked to Neoarchaean subduction-related processes. A mixed orogenicanorogenic setting is suggested for some shoshonitic lamprophyres, which is explained by subduction-accretion related metasomatism of the mantle wedge, followed by the SCLM metasomatism by asthenospheric melts/fluids. Combining petrology, geochemistry and geochronological constraints, Paul et al review the Proterozoic alkaline rocks and carbonatites (ARCs) of Peninsular India. Distinct phases of alkaline magmatism (2533-2340 Ma, 1510-1242 Ma, 833$572 \mathrm{Ma}$ ) and metamorphic events (950-930 Ma; 570-485 Ma) are identified. ARCs, generated in intra-continental rift setting (beginning Wilson cycle), and is sourced from SCLM, enriched by subducted crust or mantle-fluids. Early-formed ARCs, it is argued, underwent extensive melting with renewed rifting at $\sim 100 \mathrm{~km}$ depths during collision (Wilson cycle termination).

\section{Phanerozoic Magmatism}

After the cessation of End-Neoproterozoic LIP events there was no major igneous activity in Indian sub-continent for about 400 million years (with sporadic forays during Cambrio-Ordovician periods). This quiescence was eventually shattered with major igneous activities akin to LIPs during Cretaceous period. These include (i) Early Cretaceous igneous activities including (a) alkaline/ultra-alkaline, carbonatite intrusive activity widespread in eastern and northeastern India; (b) tholeiitic and alkaline volcanic event in Jharkhand, West Bengal and Meghalaya commonly referred to as Rajmahal Traps and (c) intrusions of minette-lamproite affinity pervasive in coal fields of Damodar valley and (ii) Late Cretaceous outpouring of lavas in the Deccan plateau.

The volcanic activity in Deccan Volcanic Province (DVP) was initiated at about 66 million years ago and apparently lasted only for a few 10s of thousands of years. It is estimated that when this massive igneous event came to an end it covered almost half of the present day Indian landmass. Much of it is, apparently, lost during subsequent geodynamic events and that the current aerial extent of about 0.5 million sq. kms represents only $1 / 3$ of what was originally constituted the DVP.

Vivek Kale and his co-workers present a succinct review of the existing knowledge on DVP. These authors bring to the fore the explicit relationship between the DVP and Reunion hotspot. The structure, tectonics, DVP basement, physico-chemical nature of the volcanics, their caught-up mantle and/or crustal xenoliths, trails of paleomagnetic signatures, trapped paleontological remains, 
volcanology, geochronolgy and related subjects are reviewed to describe contemporary models of ascent, mode, mechanism and timing of eruption and spread of large volumes of lava on continental setting through dyke-fed fissures (Iceland type basalt flooding). The exhaustive review facilitated the authors to conclude that the DVP does not have a unified eruptive history but instead the lava vented in different provinces at different times. Each of the province has unique basement resulting in province-specific contamination during ascent affecting the net chemistry of the lavas and thus posing sever constraints on the chemical proxies that are in vogue. In view of lack of adequate evidence for the pristine chemistry, the authors advocate zonal DVP stratigraphy rather than the chemo-stratigraphy. The authors call for a multifaceted and interdisciplinary study to address the gaps in our knowledge. Such a study, it is contended, will facilitate better understanding of this largest flood basalt activity on planet earth and its link to precise evaluation of the End-Cretaceous mass extinction episodes.

R. K. Srivastava reviewed the work carried out on the Early Cretaceous ( 110-118 Ma) alkaline/ultralkaline silicate and carbonatite magmatic activity of eastern and northeastern India. This magmatic activity is linked to the Kerguelen hot spot where in the latter is considered responsible for providing heat energy to tiger melt generation at mantle depths for generation of alkaline-ultra-alkaline magmas. The geochemical signatures of the intrusive bodies favor low-pressure crustal contamination, crystal accumulation and fractional crystallization and do not support the concept of mantle heterogeneity in this part of the Indian region. The author relates this pervasive intrusive event to the Greater Kerguelen Large Igneous Province that have impact on the Gondwana Supercontinent reconstructions.

The subduction of Indian Plate beneath the Southeast Asian Plate initiated during Early Cretaceous following the Gondwanaland breakup led to the formation of the Indo-Burma range and the Andaman arc-trench system comprising the Andaman-Nicobar islands. The Andaman subduction zone is one of the few modern accretionary convergent margins where all the important components of a convergent margin are exposed including a trench, an outer arc accretionary prism, a forearc, a volcanic arc and a back arc basin.

The Sumatran and central Burmese volcanic chains of Holocene and Quaternary ages respectively constitutes the active SE Asian Volcanic arc rim. In Indian subcontinent one active volcano at Barren islands and another dormant volcano at Narcondam island represents the Quaternary volcanic chain in the Andaman Java subduction complex. While reviewing the extensive work of the Geological Survey of India on these two volcanoes and supplementing it with his own new data, Tapan Pal presents geomorphic anatomy of the volcanic calderas, describes the field, petrochemical and mineralogical characteristics of recently erupted lavas and chronicles their eruptive histories during the recent past. Despite being located on the same arc line, Pal records contrasting geochemical signatures from the two volcanoes, prompting him to cast aspirations on their cogenesis and/ or consanguinity.

Saha et al reports new petrological and geochemical data of submarine volcanic rocks dredged from six different locations in the Andaman arc during the cruise SSK 033. Their study confirms that the (i) submarine volcanic rocks belong to a calc-alkaline basalt-andesite- dacite-rhyolite (B-A-D-R) spectrum generated during variable interactions between subducted oceanic slab and sub-arc mantle wedge with influx of subduction derived fluids and sediments during intermediate stage of subduction and (ii) geochemical signatures collectively suggest metasomatic enrichment of a depleted mantle wedge associated with a Mariana-type subduction system. This study is in compliance with (i) subduction of old, cold, thick and dense Indian ocean lithosphere beneath the Burmese Plate and (ii) Marianatype subduction and dehydration of old, cold, thick and dense Indian ocean lithosphere beneath the Burmese Plate.

\section{The Himalayan Orogen}

This young and active mountain belt presents a unique opportunity to examine the orogenic geological processes at various structural levels. Besides large scale tectonism, marine to terrestrial sedimentary processes, evolution of foredeep, magmatism typical to convergent margins, metamorphic rocks as archives of not only the transport of shallow rocks to deep crustal and mantle depths but also of their exhumation and the evolution of organism through fossil records have been worked out from the Himalayan orogen.

Thakur et al. have linked evolution of piggy-back Kangra Basin with reactivation of the Jawalamukhi Thrust (JT) and its deposition pattern to erosion of Dhauladhar Range, NW Himalaya. Eastern parts of this range are characterized by focused high precipitation, microseismicity and formation of the Kangra Basin, whereas western part lacks these features. This post-Siwalik intermontane basin has basin-fill essentially from the Dhauladhar Range and is developed due to foreland propagating JT. Similar OSL ages from basinal sediments and fluvial strath terrace surfaces across its hanging wall indicate late Quaternary reactivation of thisthrust. Synchronous formationof the Kangra Basin, and its filling through erosion of the Dhauladhar Range is, thus, established with reactivation of the JT.

Jain et al. observed juxtaposition of distinct terranes across the Main Central Thrust Zone (MCTZ) where subthrust Inner Lesser Himalayan (iLH) sedimentary belt yielded nearly unimodal U-Pb detrital zircon (DZ) between 2.05 and $1.80 \mathrm{Ga}$. The MCTZ represents the Proterozoic magmatic arc having $\mathrm{U}-\mathrm{Pb}$ zircon crystallization ages of $~ 1.95$ to $1.89 \mathrm{Ga}$ as part of the Columbian Supercontinent assembly. In contrast, first appearance of the Neoproterozoic 1.05-0.85 Ga detrital zircon characterizes overthrust Great Himalayan Sequence (GHS) along the MCT, while early Paleozoic detrital zircon has first appearance in tectonically overlying Tethyan Himalayan Sequence (THS). Both the northerly $\sim 1.9$ Ga magmatic arc and the Archean Aravalli-Bundelkhand Indian craton sourced the iLH sediments, while the Neoproterozoic zircon in the GHS are derived from other distinct regions.

Singh observed different magmatic episodes in the Himalaya from Paleoproterozoic, Neoproterozoic, Cambro-Ordovician and Permian in Indian Plate; magmatism is imprinted in both the Indian and Eurasian Plates during Cretaceous and Tertiary. Magmatic peaks can be correlated with amalgamation and breakup of supercontinents: Columbia/Nuna (Paleoproterozoic), Rodinia (Neoproterozoic), Gondwanian (Cambro-Ordovician), Pangea (Permian) and Himalayan (Cretaceous to Tertiary). The Himalayan orogenesis incorporates subduction-related magmatism followed by collisional magmatism till present day. 
Pant et al. considered the Himalaya as a composite of TransHimalaya, Indus-Tsangpo Suture Zone and the main mountain belt for having a re-look at the regional metamorphic transformations in this orogen. The beginning of the Himalayan orogeny is ascribed to the Cretaceous initiation of suturing of 'island arc' with the Asian block, followed with a time gap by the underthrusting of the Indian block at $\sim 57 \mathrm{Ma}$. Differences in metamorphism of underthrust and overthrust blocks are reflected in their P-T-t evolution. Exhumation was unequal with significantly higher rates along the syntaxes. Anatectic melts produced during Tertiary metamorphism were emplaced within the Himalaya and Trans-Himalaya, possibly through crustal-scale faults.

Patel and Man Mohan investigated Mio-Pliocene tectonics and exhumation histories of the NW- and NE-Himalaya. Thermochronological/cooling age pattern, and exhumation rates vary in different parts of the Himalaya, and appear to reflect geometry and kinematics of the Main Himalayan Thrust (MHT) and its duplex structures over its ramp. These observations suggest that these ages and exhumation patterns do not mirror precipitation gradients; these are controlled by subsurface geometry of the MHT and its associated structures.

Bhargava and Singh presented geological evolution of the Tethys Himalaya since late Precambrian where sedimentation continued up to late Cretaceous with intermittent breaks. Onset of late Cambrianlower Ordovician Kurgiakh orogeny terminated the Cambrian sequence. Sedimentation resumed during lower-middle Ordovician by shallow marine transgression. Siliclastic-carbonate sedimentation continued up to the Tournaisian, finally terminating with a late Carboniferous-early Permian glaciation and outpouring of $290 \mathrm{Ma}$ Panjal Volcanics. The Changhsingian transgression was extensive; except Kashmir, the Wuchiapingianis absent with a marked hiatus between Changhsingian and Induan (Permo-Triassic). The TriassicLias succession is characterized mainly by carbonates throughout, ending towards the Lias; the hiatus spanned the Late OxfordianKimmeridgian. Except Kashmir, the Kimmeridgian transgression covered the remaining Tethyan sector. In the Cretaceous, the plate margin became active with deposition of deeper water sediments.

Kumar investigated Late Cenozoic Siwalik Group of the western Himalayan foreland basin where response of allogenic forcing were reviewed at variable timeframe. Upward stratigraphic coarsening sequence of the Siwalik succession was initiated at $\sim 13 \mathrm{Ma}$ and deformed by the Himalayan Frontal Thrust (HFT) at $\sim 0.2$ Ma. A large river evolved around $10 \mathrm{Ma}$ with southward propagating mountain front after 5 Main proximity of the Main Boundary Thrust (MBT). Major surface uplift took place at 5 Ma all along the Himalaya and generated much of the modern drainage system.

\section{Palaeobiodiversity and Palaeobiology of the Indian Subcontinent}

The Indian subcontinent has a unique geological history of being an integral part of southern supercontinent Gondwanaland, subsequently rifting from it, and drifting towards the north in isolation over thousands of kilometres to collide with Asian mainland that resulted in the formation of Himalayan mountain chain. The fossil assemblages from different chronostratigraphic units of the Himalayan and peninsular Indian regions, spanning Cambrian-Palaeogene time interval, offer important insights into Cambrian biozonation and biogeographic relationships of the Tethys Himalaya, diversity, evolution and intercontinental affinities of vertebrates prior to the break-up of India from Gondwanaland, patterns of evolution and dispersals of life forms during India's physical isolation from other landmasses, and chronology of development of lignite deposits along the western margin of India prior to its collision with Asia.

B.P. Singh and O.N. Bhargava discuss biozonation, depositional environments, and biogeographic affinities of the Cambrian sequences of the Lesser and Tethyan Himalayas. According to them, currently the Cambrian biozonation exists for four stratigraphic intervals in the Lesser Himalaya and for two stratigraphic intervals in the Tethys Himalaya. The authors articulate different perceptions on depositional settings of the Cambrian sequences of the Lesser and Tethys Himalayas. In their view, the Cambrian fauna of India demonstrates close biogeographic relationships with Gondwanan and periGondwanan landmasses. The authors also discuss briefly the Ediacaran - Cambrian boundary in peninsular India (Bikaner Basin) and recent evidences for delineating this stratigraphic boundary in the Lesser Himalaya.

In the following paper, Saswati Badyopadhyay and Sanghamitra Ray critically review the diversity, evolution and intercontinental relationships of Late Permian-Middle Jurassic vertebrate fossils derived from 12 Gondwana stratigraphic units of peninsular India that represent pre-Gondwanaland break-up fauna. The authors discuss major evolutionary transitions between Late Permian and Middle Jurassic and important biotic turnovers at Permian-Triassic and Triassic-Jurassic transition at global level in brief and show how Gondwana fossil record of India mirrors some of the evolutionary changes and macroevolutionary patterns observed in other continents. They also discuss the significance of the Indian Gondwana vertebrate fossils as important biostratigraphic makers for intercontinental correlation.

The evolution and biogeographic links of fauna and flora during Indian plate's northward journey is the focus of following three papers. Varun Parmar and G.V.R.Prasad critically evaluate the vertebrate fossil record for the early and late drift phases of India's northward drift. Their study reveals very limited data for the early drift phase, but the fossil record from the late drift phase presents a complex biogeographic history of hosting both Gondwanan and Laurasian taxa as well as some endemic forms. To explain the close phylogenetic relationships of Late Cretaceous vertebrate taxa between India and Madagascar, the authors propose that the Seychelles, Amirante Ridge, Providence Bank, and some microcontinental fragments formed a possible terrestrial connection between these two landmasses. Likewise, they suggest that the island-arc systems north of Greater India (Oman, Kohistan, and Dras) served as stepping stones for the dispersal of Laurasian taxa into India.

Prior to its collision with Asia, the Indian plate lying in an equatorial belt hosted several lignite deposits on its western margin (Gujarat and Rajasthan). These lignite deposits have been an important source of terrestrial and marine vertebrate, invertebrate and plant fossils. Vandana Prasad et al report a rich assemblage of dinoflagellate cysts from the Akli Formation exposed in the Giral Lignite Mine, Bamer (Rajasthan). As the dinoflagellate biozonation favors a Danian-Thanetian (Palaeocene) age for the Akli Formation, 
they argue that this is the oldest lignite deposit on the western margin of India in comparison to the late Thanetian-early Ypresian age of Cambay and Kutch lignite deposits and the lignite deposits of western India formed diachronously. The authors also identify five depositional units for the Akli Formation in a sequence stratigraphic framework based on lithological characters, distribution pattern of dinoflagellate cysts, mangrove and terrestrial pollen.

The drifting Indian plate has been considered as a center of origin for several mammalian groups (e.g., Primates, Perissodactyla, Artiodactyla), which dispersed out of India following India-Asia collision. In their paper, Sunil Bajpai and V.V. Kapur throw light on recent fossil finds from the Early Eocene of India, at a time when Neotethys was receding, India was docking with Asia and green-house conditions prevailed on the Earth. The authors briefly discuss important Early Eocene mammalian clades of Indo-Pakistan and their significance in understanding biogeographic origins, evolutionary radiations, and dispersal patterns. They show that some of the mammalian groups such as whales and perissodactyls originated in the Indian subcontinent and later dispersed to other landmasses and thus support Out-of-India dispersal hypothesis.

\section{Quaternary and Recent}

Section on "Quaternary and recent” incorporates five papers designed so as to demonstrate how a climate-tectonic continuum from arid Trans Himalayan regions to wet southern Himalayan front and Ganga-Brahmaputra foreland has evolved. Authors discuss the work published during the last decade and present a synoptic view of Quaternary landscape evolution vis-à-vis climate and tectonics operating in the region.

The rivers of Himalaya and foreland evolved in response to tectonics of thrust and fold belt of Himalaya and varying strength of India Summer Monsoon and the paper on "Late Quaternary sedimentation history of the Himalaya and its foreland: clues from fluvial landscape" by Kumar et al. presents almost 100 ka history of this active landscape. Amal Kar and Anil Kumar, in their paper, present an overview of arid landscape incorporating evolution of cold Ladakh and warm Thar deserts and describe fluvio-aeolian processes from the two arid zones of contrasting tectonic setups. The study by Jain et al. provides a geological and geomorphic overview of different types of river basins of India and based on tectonic, climate and geomorphic setting classified these river basins into six groups and presented their evolutionary histories accordingly. Saini et al. describe the case and status of studies on the lost river Saraswati and discus it in context of the role of climate change and active faults of Himalaya. Possible influence of basement structures like the Delhi-Sargodha Ridge and seismicity of the Haryana plains in abandonment of Saraswati river system is also evaluated. Likewise, climate-society linkages are evaluated by Mishra et al that present review of published literature on Holocene monsoonal variability and how societies of the Indus valley civilization responded and evolved.

\section{Advances in Antarctic and Ocean Research}

Antarctica, the Indian sub-continent, and the oceans contiguous to these two landmasses occupy key positions for an increased understanding of the evolution of the supercontinents Rodinia and
Gondwana, the present-day global plate motion kinematics, the opening of the Indian Ocean which in turn is linked to the fragmentation and dispersal of the Gondwanaland, and the development of the eastern and western continental margins of the Indian mainland as passive entities. While our understanding of the evolutionary history of these domains has been impressive over the past few decades of sustained investigations, the studies have also thrown up many challenges such as the reason (s) for the inferred differences in the style and the processes of breakup and separation along the Antarctic margins, the definition and delineation of the continent-ocean boundaries of the Antarctic and Indian continental margins, the inter-relationship between the various magmatic bodies exposed in the Central Dronning Maud Land sector of East Antarctica, the crustal configuration as well as the extent of the postulated microcontinental slivers in the Northern Indian Ocean etc.

Antarctica and the surrounding oceans have also been suggested to play a critical role in the global climate system. For instance, some of the recent studies bring out a strong coupling of the Asian monsoon and Antarctic climate on sub-orbital millennial timescales. At the same time however, comparisons of the Indian paleoclimate record over the last glacial period with the Antarctic ice core and sea-surface temperature records from the Southern Ocean do not appear to suggest a dominant role of Southern Hemisphere climate processes in regulating the Indian summer monsoon variability. In contrast, it has also been postulated by others that the Indian summer monsoon is sensitive to Antarctic sea-ice loss.

The three papers in this Section represent an attempt to capture some synthesized concepts, some unresolved problems and some real examples of the contributions by Indian geoscientists in the three different domains- the rock record spread over parts of Central Dronning Maud land (CDML) and the Larsemann Hills in East Antarctica, the paleoclimatic records from coastal Antarctica and the surrounding Southern Ocean, and the structural and tectonic features of the Indian continental margin and the adjacent ocean basins. Although the focus is on the Indian contributions, the three papers go beyond a strictly uni-dimensional approach and highlight some of the multi-national endeavors in addressing the challenges of Antarctic and Indian Ocean geosciences.

Geoscientific component has been an integral part of every Indian Scientific Expedition to Antarctica ever since the first expedition nearly 40 years back, resulting in a wealth of data on geology, geomorphology, geophysics and glaciology. The paper by Rasik Ravindra and Rajan provides an overview of the work by Indian geoscientists in deciphering the geological, tectonothermal, structural and metamorphic history of the poly-deformed high-grade rocks of the CDML-Larsemann Hills areas. Considering that Antarctica was a keystone of Gondwanaland of which the Indian landmass was an intrinsic part, one of the overarching goals of the sustained Indian endeavours has naturally been to understand the crustal evolution and geodynamics of the Antarctic continent and a best fit model for India and Antarctica prior to the Gondwana amalgamation and split.

Proxy records of the climate system from the ice cores of Antarctica as well as the sediment archives from the Antarctic lakes and the Southern Ocean provide a detailed record of global climatic conditions dating back to the Holocene and the last glaciations. Thamban Meloth in his paper highlights the contributions by Indian scientists towards understanding the past dynamics and variability of Antarctic climate, ice sheet processes, oceanic changes and the biogeochemical processes. Available ice core information clearly 
suggests that the CDML is a unique region in East Antarctica that provides a window of opportunity to study the past variabilities in westerly winds, sea ice and climate over the late Holocene and their possible linkages to the tropical climate. The studies also reveal the utility of shallow ice cores in reconstructing the past changes in the decadal to inter-decadal climate modes like the Southern Annular Mode (SAM), El-Nino-Southern Oscillation (ENSO), Pacific-South American mode (PSA), and the Pacific Decadal Oscillation (PDO). In contrast to the studies on ice cores which have been confined to high-resolution reconstruction of climate variability during the past few centuries, Antarctic lake sediment records as well as the marine records from the Indian sector of the Southern Ocean records have focussed on long-term millennial-scale regional climate variability, especially during the late Quaternary. The recent collaborative initiatives by Indian scientists under the International Ocean Discovery Program have opened up another vista to go further back in time, as Meloth rightly points out.

The passive eastern and western continental margins of the Indian mainland have been shaped by episodes of rifting and breakup of the Gondwanaland, the northward movement of India relative to Antarctica, episodes of ridge jumping, interaction with hotspots, widespread volcanic activity, collision between the Indian and Eurasian plates and the rise of the Himalayas, accelerated erosion of the Himalayas and consequent development of two of the world's thickest accumulations of sediment draping the present-day seabed. All these episodes have left in their wake several structural and tectonic features ranging from aseismic ridges/submarine plateaus to seamounts, possible microcontinental slivers and ocean basins on the margins. The paper by Yatheesh looks at our current status of knowledge on these structural and tectonic features of the continental margins. While describing the characteristics of many of these prominent features and their documented evolutionary histories, Yatheesh also dwells at length on some of the challenging questions related to the evolutionary history of the Indian Ocean that need to be addressed, such as the locations of the continentocean boundaries of the Indian continental margins, the timing of formation of the deep offshore basins on the margins, the crustal configuration as well as the extent of the postulated micro-continental slivers, the cause of intense seismicity over the Chagos Bank segment of the Laccadive-Chagos Ridge etc.

\section{Geophysical Studies}

The crustal and lithospheric structures are often used to develop geodynamic and tectonic models of the geological provinces and also to elucidate the intraplate and plate boundary earthquake generating processes. The four interesting contributions covering geophysics and seismology primarily review and present structure of the crust and lithosphere under the diverse geological terranes of the Indian continent as well as to document present-day seismicity. These articles utilize four different methods, Gravity, Magnetotelluric (MT), Controlled Source Seismic and Earthquake Seismology in bringing out remarkable deep structural features that were hitherto unknown.

Kumar et.al., present gravity anomaly maps covering Indian subcontinent and surrounding ocean prepared from the hybrid data sources and discuss the origin of continental-scale gravity anomalies and the corresponding lithospheric density structures. It is observed that the gravity anomalies are trending parallel to major surface geological structural patterns of the Indian subcontinent, suggesting the extension of surface features to the subsurface levels. They have presented a lithospheric density model along a profile cutting across Indian subcontinent based on integrated analyses of gravity and geoid anomalies together with topographic and heat flow data.

Several active and passive seismic experiments have extensively enriched the knowledge of the crust and lithospheric structure of the Indian sub-continent. Tewari and Kumar have summarized numerous studies with detailed description of Crust-Mantle interface, crustal scale faults and seismic velocity models across several postulated Precambrian shear and suture zones, rift basins and other geological terrenes and favour the Plate Tectonic evolutionary model. In addition to lithospheric studies, they have also presented the results for $660 \mathrm{~km}$ depth discontinuities under the Indian plate using seismological data.

P.K. Patro has deliberated the electrical signatures of the subsurface structure across some of the important geological provinces of the Indian lithosphere using magnetotelluric (MT) studies. He has informed about a mobile application based on Android operating system MTApp, which gives the information about the published MT models and the sounding curves over different geological terrains of India. This paper documents the electrical structures corroborating with geological models and also in finding of the Electric Moho in the Eastern Indian Craton suggesting absence of conducting continental lower crust in this region.

Kayal and Padhy have presented a short review on the seismicity and crust-mantle structure of the Indian subcontinent. They have underlined that seismicity regions in India range from stable continental regions to plate boundary regions and is categorized into four zones (BIS, 2002); Zone II: seismically less active, Zone III: moderately active, Zone IV: highly active, while the Zone V represents highest activity. They have thoroughly described the different aspects of seismology and its applications such as seismicity modelling, seismic anisotropy, attenuation, ambient seismic noise etc. They have emphasized the need of strengthening seismological network for preparing a seismic catalogue with a magnitude completeness as small as possible, to obtain a fine-scale high-resolution structure for ground motion prediction and for seismic hazard microzonation.

\section{Concluding remarks}

This compilation makes an attempt to cover not only the range of geological time represented within the Indian sub-continent but also to showcase special rocks such as lamprophyres, kimberlites and carbonatites as well as describe the paleobiodiversity and paleobiology of the terrain. Two special sections i.e. on Polar research and Geophysics form part of the ten sections. The effort involved ten section editors and nearly one hundred authors for the forty two papers and represents culmination of an initiative which began with a much larger community of geoscientists. It is hoped that the reviews with up to date and extensive reference lists will be useful to the larger community.

\section{Acknowledgments}

The editorial team of this special issue thanks the Legacy Committee (comprising of Fareeduddin, NC Pant, Saibal Gupta, Sathyapratha Guha, K.S. Godhavari, Debasish Rout, Basab 
Mukhopadhyay, V. Aneel Kumar and Nabanita Nandi) for inviting us to prepare the $36^{\text {th }}$ IGC Legacy Volume. Our grateful thanks to Prof. Jin-Yong Lee, Editor-in-chief, Episodes, Prof. Stanley Finney, Secretary General, IUGS and Prof. Doleres Periera, Chair, Publication Committee IUGS for all the help and encouragement that were extended right from planning, execution and publication stage of this special Issue. We thank Dr. Rasik Ravindra, Secretary General, 36 ${ }^{\text {th }}$ IGC and Prof. A. K. Singhvi, Vice President INSA for their constant encouragement. Dr. Sumeet Ray, Former Deputy Director General, Geological Survey of India is thanked for keen interest and providing useful inputs for the Introduction chapter. We thank Mr. M. Nagraju, Printer, Driti Enterprises for all his diligent work done, despite a very short notice. Our special thanks to the reviewers (a number too large to be enumerated here) for their cooperation and support.

\section{References}

Bajpai, Sunil and Kapur, Vivesh V. (2020) India's geodynamic evolution during the Eocene: perspectives on the origin and early evolution of modern mammal orders. Episodes, 43(1), 489-497. https://doi.org/10.18814/epiiugs/2020/020031

Bandyopadhyay, Saswati and Ray, Sanghamitra. (2020) Gondwana Vertebrate Faunas of India: Their Diversity and Intercontinental Relationships. Episodes, 43(1), 438-460. https://doi.org/ 10.18814/epiiugs/2020/020028

Bhargava O.N \& Singh, B P. (2020) Geological evolution of the Tethys Himalaya. Episodes, 43(1), 429-437. https://doi.org/10.18814/ epiiugs/2020/020027

Bhaskar Rao, Y.J., Vijaya Kumar, T., Sreenivas, B and Babu, E.V.S.S.K. (2020). A Review of Paleo- to Neoarchean crustal evolution in the Dharwar Craton, Southern India and the transition towards a Plate Tectonic regime. Episodes, 43(1), 51-68. https:/ doi.org/10.18814/epiiugs/2020/020003

Boyet, M. and Carlson, R.W., 2006, A new geochemical model for the Earth's mantle inferred from Sm-146-Nd-142 systematics. Earth and Planetary Science Letters, v. 250, p.254-268.

Chakraborty, Partha., Mukhopadhyay, Joydip., Paul, P.P., Banerjee, D.M. and Bera, M.K. (2020) Early atmosphere and hydrosphere oxygenation: Clues from Precambrian paleosols and chemical sedimentary records of India. Episodes, 43(1), 175-186. https:// doi.org/10.18814/epiiugs/2020/020011

Chalapathi Rao, N.V., Giri, Rohit K., Sharma, Abhinay and Pandey, Ashutosh. (2020) Lamprophyres from the Indian shield: A review of their occurrence, petrology, tectonomagmatic significance and relationship with the Kimberlite rocks. Episodes, 43(1), 231-248. https://doi.org/10.18814/epiiugs/2020/020014

Chattopadhyay, Anupam., Bhowmik, Santanu Kumar and Roy, Abhinaba. (2020)Tectonothermal evolution of the Central Indian Tectonic Zone and its implications for Proterozoic supercontinent assembly: the current status. Episodes, 43(1), 132-144. https:// doi.org/10.18814/epiiugs/2020/020008

Chaudhuri, T., and Mazumder, R. 2019. Detrital zircons reveal evidence of Hadean crust in the Singhbhum craton, India: a discussion. J. Geol. 127:381-385. Chaudhuri, T.; Wan, Y.; Mazumder, R.; Ma, M.; and Liu, D. 2018. Evidence of enriched, Hadean mantle reservoir from 4.2-4.0 Ga zircon xenocrysts from Paleoarchean TTGs of the Singhbhum craton, eastern India. Nat. Sci. Rep. 8:7069.

Compston, W., Kinny P.D., Williams, I.S., and Foster, J.J., 1986, the age lead loss behavior of zircons from the Isua supracrustal belts as determined by ion microprobe. Earth Planetary Science Letters, v. $80, \mathrm{p} 71-81$.
Cui, P.L., Sun, J.G., De-Ming Sha, Wang, X.J., Zhang,P., Gu, A.E., and Wang, Y.Z., 2013, Oldest zircon xenocryst (4.17 Ga) from the North China Craton, International Geology Review, v. 55(15), p1902-1908, DOI: 10.1080/00206814.2013.805925

Dasgupta Somnath (2020) Petrological evolution of the Eastern Ghats Belt- Current status and future directions Episodes, 43(1), 124131. https://doi.org/10.18814/epiiugs/2020/020007

Duo, J., Wen, C. Q., Guo, J. C., Fan, X. P. and Li, X. W.,2007, 4.1 Ga old detrital zircon in western Tibet of China. Chinese Science Bulletin, v. 52, p23-26.

Fareeduddin and Banerjee, D. M.(2020) Aravalli Craton and its Mobile Belts -An Update. Episodes, 43(1), 88-108. https://doi.org/ 10.18814/epiiugs/2020/020005

Froude, D. O., Ireland, T. R., Kinny, P. D., Williams, I. S., Compston, W., Williams, I. R., and Myers, J. S., 1983, Ion microprobe identification of 4100-4200 Myr-old terrestrial zircons: Nature, v. 304, p.616-618.

Harrison, T.M., Blicher-Toff, J., Muller, W., Albarade, F., Holden, P. and Mojzsis, S.J.,2005, Heterogeneous Hadean hafnium: Evidence of continental crust at 4.4 to 4.5 Ga. Science, v.310, p.1947-1950

Harrison T.M., Schmitt A.K., McCulloch M. T. and Lovera O.M., 2008, Early (?4.5Ga) formation of terrestrial crust: Lu-Hf, ?18O, and Ti thermometry results for Hadean zircons. Earth and Planetary Science Letters, v.268, p.476-486

Heinrich, E. W. 1966. The Geology of Carbonatites. Rand McNally \& Co., Chicago, 555 pp.

Iizuka, T, Komiya, T, Johnson, S.P., Kon, Y., Maruyama, S. and Hirata, T. ,2009, Reworking of Hadean crust in the Acasta gneisses, northwestern Canada: Evidence from in-situ Lu-Hf isotope analysis of zircon. Chemical Geology, v.259, p.230-239

Iizuka, T., Campbell, I. H., Allen, C. M., Gill, J. B.,Maruyama, S. and Makoka, F., 2013, Evolution of the African continental crust as recorded by $\mathrm{U}-\mathrm{Pb}, \mathrm{Lu}-\mathrm{Hfand} \mathrm{O}$ isotopes in detrital zircons from modern rivers. Geochimca Cosmochimca Acta, v.107, p96120.

Jain, AK., Mukherjee, P.K. and Singhal Saurabh. (2020) Terrane characterization in the Himalaya since Paleoproterozoic. Episodes, 43(1), 346-357. https://doi.org/10.18814/epiiugs/2020/020021

Jayant Pati. (2020) Evolution Of Bundelkhand Craton. Episodes, 43(1), 69-87. https://doi.org/10.18814/epiiugs/2020/020004

Kar Amal and Kumar Anil. (2020) Evolution of arid landscape in India and likely impact of future climate change. Episodes, 43(1), 511-523. https://doi.org/10.18814/epiiugs/2020/020033

Kumar Rohtas. (2020) Late Cenozoic Himalayan foreland basin: Sedimentologic attributes. Episodes, 43(1), 417-428. https:// doi.org/10.18814/epiiugs/2020/020026

Kumar, Anil., Ray, Yogesh., Ghosh, Rupa., Bandyopadhyay, Sujay., Singh, Vimal., Srivastava, Pradeep. (2020) Late Quaternary Evolution of Himalaya and its foreland: clues from fluvial landscape. Episodes, 43(1), 498-510. https://doi.org/10.18814/ epiiugs/2020/020032

Kumar, Niraj., Singh,A.P. and Tiwari, V.M. (2020) Gravity Anomalies, Isostasy and Density Structure of the Indian Continental Lithosphere. Episodes, 43(1), 609-621. https://doi.org/10.18814/ epiiugs/2020/020040

Kumar, Santosh., Gupta, Saurabh., Sensarma, Sarajit and Bhutani, Rajneesh. (2020) Proterozoic felsic and mafic magmatism in India: Implications to crustal evolution through crust-mantle interactions. Episodes, 43(1), 203-230. https://doi.org/10.18814/epiiugs/2020/ 020013

Meloth Thamban. (2020) Palaeoclimatic records from Antarctica and Southern Ocean: A review of Indian contributions. Episodes, 43(1), 575-585. https://doi.org/10.18814/epiiugs/2020/020038 
Miller, S. R.; Mueller, P. A.; Meert, J. G.; Kamenov, G. D; Pivarunas, A. F.; Sinha, A. K; and Pandit, M. K. 2018. Detrital zircons reveal evidence of Hadean crust in the Singhbhum craton, India. J. Geol. 126:541-552.

Miller, S. R.; Mueller, P. A.; Meert, J. G.; Kamenov, G. D; Pivarunas, A. F.; Sinha, A. K; and Pandit, M. K. 2019. Detrital zircons reveal evidence of Hadean crust in the Singhbhum craton, India: A reply. J. Geol. 127:387-392.

Moorbath, S., Whitehouse, M. J. and Kamber, B.S.,1997, Extreme Nd-isotope heterogeneity in the early Archaean fact or fiction? Case histories from northern Canada and West Greenland, Chemical Geology, v.135, p.213-231

Mojzsis, S.J., Coath, C.D., Greenwood, J.P., Mckeegan, K.D. and Harrison, T.M., 2003, Confirmation of mass-independent isotope effects in Archean (2.5 - $3.8 \mathrm{Ga}$ ) sedimentary sulfides as determined by ion microprobe analysis. Geochimca Cosmochimca Acta, v.67, p.1635-1658.

Mukhopadhyay, Dhruba and Matin, Abdul. (2020) The Architecture and Evolution of the Singhbhum Craton. Episodes, 43(1), 19-50. https://doi.org/10.18814/epiiugs/2020/020002

Naqvi, S. M. (2005). Geology and Evolution of Indian Plate (From Hadean to Holocene, 4 Ga to 4 Ka). New Delhi Capital Publishing Company, New Delhi, pp 450.

Pal Tapan. (2020) Quaternary Volcanoes Of Indian Subcontinent: An Overview. Episodes, 43(1), 312-322. https://doi.org/10.18814/ epiiugs/2020/020018

Pant, N C., Sing, Preeti and Jain, A.K. (2020) A Re-look at the Himalayan metamorphism. Episodes, 43(1), 369-380. https:// doi.org/10.18814/epiiugs/2020/020023

Parmar, Varun and Prasad G.V.R. (2020) Vertebrate evolution on the Indian raft - Biogeographic conundrums. Episodes, 43(1), 461475. https://doi.org/10.18814/epiiugs/2020/020029

Patel, R.C. and Man Mohan. (2020) Mio-Pliocene Tectonics and Exhumation Histories of the NW- and NE-Himalaya. Episodes, 43(1), 381-403. https://doi.org/10.18814/epiiugs/2020/020024

Patranabis-Deb,Sarbani and Saha, Subhojit. (2020) Geochronology, paleomagnetic signature and tectonic models of cratonic basins of India in the backdrop of Supercontinent amalgamation and fragmentation.Episodes, 43(1), 145-163. https://doi.org/10.18814/ epiiugs/2020/020009

Paul, Debajyoti., Chandra., Jyoti and Halder, Mahesh. (2020) Proterozoic Alkaline rocks and Carbonatites of Peninsular India: A review. Episodes, 43(1), 249-277. https://doi.org/10.18814/ epiiugs/2020/020015

Prasad, Vandana Uddandam., Prem Raj., Agarwal, Shailesh., Bajpai, Sunil., Singh, Indrabir., Mishra, Ashish K., Sharma, Anupam, Kumar Madhav and Verma Poonam. (2020) Biostratigraphy, palaeoenvironment and sea level changes during pre-collisional (Palaeocene) phase of the Indian plate: palynological evidence from Akli Formation in Giral Lignite Mine, Barmer Basin, Rajasthan, Western India. Episodes, 43(1), 476-488. https:// doi.org/10.18814/epiiugs/2020/020030

Prasanta K Patro. (2020) Electrical conductivity structure along a few transects over the Indian Lithospheric domains. Episodes, 43(1), 638-649. https://doi.org/10.18814/epiiugs/2020/020042

Praveen K. Mishra, Parth R. Chauhan, Pranaya Diwate, Shah Parth and Ambili Anoop. (2020) Holocene climate variability and cultural dynamics in the Indian subcontinent. Episodes, 43(1), 552-562. https://doi.org/10.18814/epiiugs/2020/020036

Radhakrishna, T, and Kumar, K. Vijaya. (2020) Palaeoproterozoic Mafic magmatism in the Indian Shield: Petrologic, Geochemical and Thermal constraints on Proterozoic Mantle. Episodes, 43(1), 187-202. https://doi.org/10.18814/epiiugs/2020/020012

Ravindra Rasik and Rajan, S. (2020) Advances in Antarctic geoscience studies: Indian contributions. Episodes, 43(1), 563-574. https:// doi.org/10.18814/epiiugs/2020/020037

Saha, Abhishek., Mudholkar., Abhay V. and Kamesh Raju, K.A. (2020) Magma genesis at Andaman volcanic arc regime, Northeastern Indian Ocean: Role of slab-mantle interaction Episodes, 43(1), 323-334. https://doi.org/10.18814/epiiugs/2020/020019

Saini, H. S., Apurva Alok and N.C. Pant. (2020) The Lost Saraswati River of Northwestern Indian Plains: Status and way forward. Episodes, 43(1), 524-534. https://doi.org/10.18814/epiiugs/2020/ 020034

Sarkar, Subir., Banerjee, Santanu and Chakraborty, Partha Pratim. (2020) Microbial Mat Structures and role of microbes in Precambrian siliciclastic sedimentation: Evidence from Indian Proterozoic basins. Episodes, 43(1), 164-174. https://doi.org/ 10.18814/epiiugs/2020/020010

Singh Sandeep. (2020) Himalayan magmatism through space and time. Episodes, 43(1), 358-368. https://doi.org/10.18814/epiiugs/ 2020/020022

Singh, BP \& Bhargava ON. (2020) Cambrian of the Himalaya and the Peninsular India- Biozonation, Depositional Environments and Biogeographic Provinces. Episodes, 43(1), 404-416. https:/ /doi.org/10.18814/epiiugs/2020/020025

Sreenivas, B., Dey, S., Bhaskar Rao, Y.J., Vijaya Kumar, T., Babu, E.V.S.S.K. and Williams, I.S., In press. A new cache of Eoarchaean detrital zircons from the Singhbhum craton, eastern India and constraints on early Earth geodynamics. Geoscience Frontiers. DOI: 10.1016/j.gsf.2019.02.001

Srivastava Rajesh K. (2020) Early Cretaceous alkaline/ultra-alkaline silicate and carbonatite magmatism in the Indian Shield - a review: implications for a possible remnant of the Greater Kerguelen Large Igneous Province. Episodes, 43(1), 300-311. https://doi.org/ 10.18814/epiiugs/2020/020017

Tewari, Harish C. and Kumar, Prakash. (2020) Lithospheric framework of the Indian sub-continent through Seismic and Seismological Studies. Episodes, 43(1), 622-637. https://doi.org/ 10.18814/epiiugs/2020/020041

Thakur, Vikram C., Joshi, M., and Suresh N. (2020)Himalayan collisional tectonics? Linking the Kangra piggy-back Basin with reactivation of the Jawalamukhi Thrust and erosion of Dhauladhar Range, Northwest Himalaya. Episodes, 43(1), 335-345. https:// doi.org/10.18814/epiiugs/2020/020020

Trail D.,Watson B.E. and Tailby N.D. , 2013, Insights into the Hadean Earth from Experimental Studies of Zircon., Journal of the Geological Society of India,v. 81, p.605-636

La Touche T. H. D. (1919). The submerged forests at Bombay. In Records of the Geological Survey of India. V. XLIX, part 4. P. 191-222

Upadhyay, D.; Chattopadhyay, S.; Kooijman, E.; Mezger, K.; and Berndt, J. 2014. Magmatic and metamorphic history of Paleoarchean tonalite-trondhjemitegranodiorite (TTG) suite from the Singhbhum craton, eastern India. Precambrian Res. 252:180190.

Valley, J.W., 2003, Oxygen isotopes in zircon. In: Hanchar, J.M., Hoskin, P.W.O. (Eds.), Zircon. Reviews in Mineralogy and Geochemistry, v.53, p.343-385.

Valley J.W., Cavosie, A.J., Ushikubo, T., Reinhard, D.A., Lawrence, D.F., Larson, D.J., Clifton, P.H., Kelly, T.F., Wilde, S.A., Moser, D.E., Spicuzza, M.J., 2014, Hadean age for a post-magma-ocean zircon confirmed by atom-probe tomography. Nature Geoscience,v. 7(3), p.219-223

Yatheesh, V. (2020) Structure and tectonics of the continental margins of India and the adjacent deep ocean basins: current status of knowledge and some unresolved problems. Episodes, 43(1), 586608. https://doi.org/10.18814/epiiugs/2020/020039 
Watson, E.B. and Harrison, T.M. ,2005, Zircon thermometer reveals minimum melting conditions on earliest Earth. Science, v.308, p841-844.

Whitehouse, M.J., Nemchin, A.A. and Pidgeon, R.T., 2017,What can Hadean detrital zircon really tell us?A critical evaluation of their geochronology with implications for the interpretation of oxygen and hafnium isotopes. Gondwana Research, v.51, p 78-91.https:/ /doi.org/10.1016/j.gr.2017.07.007
Wilson, R.W., Houseman, G.A., Buiter, S.J.H., McCaffrey, K.J.W., Dore, A.G. (2019). Fifty Years of the Wilson Cycle Concept in Plate Tectonics: an overview. In Wilson, R. W., Houseman, G. A., McCaffrey, K. J. W., Dore, A. G. \& Buiter, S. J. H. (eds) Fifty Years of the Wilson Cycle Concept in Plate Tectonics. Geological Society, London, Special Collections, 470. https://doi.org/ 10.1144/SP470-2019-58. 